\title{
Nos confins da civilização: Algumas bistórias brasileiras de Hercule Florence
}

\author{
At the edges of civilization: Some Brazilian stories, \\ by Hercule Florence
}

Francisco Foot Hardman

Professor do Departamento de Teoria Literária, Instituto de Estudos da Linguagem, Unicamp Caixa Postal 6045

13084-971, Campinas — SP

ffooth@hotmail.com

\section{Lorelai Kury}

Pesquisadora e professora da Casa de Oswaldo Cruz, Fiocruz. Professora do Departamento de História da UERJ lkury@gbl.com.br
HARDMAN, F. F. e KURY, L.: 'Nos confins da civilização: Algumas histórias brasileiras de Hercule Florence'.

História, Ciências, Saúde-Manguinhos, vol. 11(2): 385-409, maio-ago. 2004.

O artigo apresenta o texto Quelques anecdotes brésiliennes, redigido pelo viajante Hercule Florence entre 1829 e 1830, anexo ao relatório Continuation de l'esquisse du voyage de $M$. de Langsdorff... O documento foi por nós transcrito e traduzido sob o título Algumas histórias brasileiras. O manuscrito, publicado pela primeira vez aqui, é um registro de sete narrativas ouvidas provavelmente ao longo da expedição Langsdorff. Foram recolhidas, ao que consta, na tradição oral e anotadas ali como materiais específicos e passíveis de futuros estudos e pesquisas. Florence esboça a crítica da precariedade da organização da sociedade nacional nos confins da civilização, ao inaugurar-se a autonomia político-administrativa do Brasil.

PALAVRAS-CHAVE: viajantes; expedição Langsdorff; Hercule Florence; costumes brasileiros; sertão.

HARDMAN, F. F. and KURY, L.: 'At the edges of civilization: Some Brazilian stories, by Hercule Florence'.

História, Ciências, Saúde-Manguinhos, vol. 11(2): 385-409, May-Aug. 2004.

The article presents the text 'Quelques anecdotes brésiliennes', written between 1829 and 1830 by the voyager Hercule Florence and attached to the account entitled 'Continuation de l'esquisse du voyage de M. de Langsdorff...,'. We have transcribed and translated the text into Portuguese under the title Algumas historias brasileiras. Published here for the first time, this manuscript offers an initial synthetic record of seven narratives most likely heard during the Langsdorff expedition. They apparently were gathered in the oral tradition. Annotated bere, they may now be used in future studies and research. Florence drafts a criticism of the precarious organization of national society at the edges of civilization, at a moment when Brazil was inaugurating its political and administrative autonomy.

KEYWORDS: travelers, Langsdorff expedition, Hercule Florence, Brazilian customs, sertão. 
"...le coeur est partial, l'habitude puissante, les faits insidieux, et l'illusion facile..."

(Volney, Voyage en Égyte et en Syrie, 1787)

E stas Algumas histórias brasileiras de Hercule Florence eram inéditas até hoje. A única referência a elas veio por parte do minucioso historiador russo Boris Komissarov, especialista mundial no que se refere à expedição Langsdorff. ${ }^{1} \mathrm{O}$ manuscrito em que nos baseamos para esta transcrição e tradução encontra-se em Moscou. No início dos anos 1990, com o projeto Langsdorff de Volta, cópias microfilmadas dos documentos que se encontram na Rússia foram depositadas no Departamento de Arquivo e Documentação da Casa de Oswaldo Cruz e no Centro de Memória da Unicamp.

Percorrendo as microformas, em meio a uma profusão de cartas, memórias científicas e relatórios escritos em russo, alemão, francês e latim destacou-se o Continuation de l'esquisse du voyage de M. de Langsdorff..., redigido por Hercule Florence, em 1829-30, no Rio de Janeiro e em Campinas. Como anexos a este relatório, o viajante acrescenta uma memória sobre as vozes dos animais e Quelques anecdotes brésiliennes, que transcrevemos, traduzimos e publicamos aqui, sob o título Algumas histórias brasileiras. Os textos foram enviados a São Petersburgo como parte do material produzido pela expedição. A primeira parte do relatório, que se perdeu, conteria a narrativa da viagem até Cuiabá. A segunda parte — depositada em Moscou e microfilmada - começa exatamente com a descrição daquela cidade e termina com a partida dos membros da expedição de Belém, em direção ao Rio de Janeiro.

Florence, que nascera em Nice, em 1804, acabaria falecendo em Campinas em 1879, onde passara a residir desde 1830. O jovem chegara ao Rio de Janeiro em 1824 e encontrara trabalho, inicialmente, no estabelecimento de um comerciante francês. Em seguida trabalhou na livraria e tipografia de Pierre Plancher. Respondendo a um anúncio de jornal, Florence engajou-se, em 1825, como segundo desenhista e cartógrafo na expedição fluvial comandada pelo barão de Langsdorff, médico, naturalista e viajante nascido no Hessen renano e que atuava no Brasil, desde 1813, como cônsul-geral da Rússia.

A expedição Langsdorff, patrocinada pelo czar russo em clara tentativa de demonstrar que seu império nada devia às demais potências européias, escolheu, para conhecer o interior do país, realizar uma monção partindo de Porto Feliz, pelo rio Tietê, e subindo em direção ao rio Amazonas, atravessando os sistemas fluviais que permitiam a comunicação entre as províncias de São Paulo, Mato Grosso e Grão-Pará. Chegaram a Belém em dezembro de 1828, 
após uma difícil viagem, marcada pela morte trágica de Adrien Taunay, que se afogou no rio Guaporé ${ }^{2}$ e pelo adoecimento do comandante da expedição. Langsdorff perdera a razão, possivelmente por causa das febres de que padeceu. Ele encarregou Florence de continuar a redação do diário da viagem, já que não se encontrava em condições nem mesmo de saber em que dia estavam. Dos membros da expedição, Florence foi o único que publicou suas narrativas. A Viagem fluvial do rio Tietê ao Amazonas, editada pela primeira vez em 1875-77, constitui até hoje o principal relato do impressionante périplo fluvial. ${ }^{3}$

Algumas histórias brasileiras não faz parte das edições da Viagem fluvial. Posto como primeiro anexo ao final de seu relatório de viagem, este manuscrito representa sem dúvida um registro inicial, sintético, à maneira de esquetes, quadros ou minicontos, de sete narrativas ouvidas muito provavelmente ao longo da expedição Langsdorff. Foram recolhidas, ao que consta, na tradição oral que preserva e dissemina certa memória popular, anotadas ali como materiais específicos e passíveis de futuros estudos e pesquisas. Diferentemente do núcleo do relatório, que descreve, em geral, a experiência fruto do testemunho direto e da observação in situ, as Histórias são reunidas de forma mediada pelo discurso de terceiros; se não dependem da leitura de documentos ou textos, também não podem ser 'controladas' pela verificação imediata dos sentidos. As ocorrências vividas durante a monção podem ser reportadas no tempo presente, no registro do diário ou do desenho; os casos contados são apenas ouvidos como fragmentos de memórias comuns, em geral em conversas casuais e descontínuas, e sempre referidas a tempos pretéritos. Nenhuma das 'histórias' se passa em lugares efetivamente percorridos pela expedição. O registro, aqui, ocupa função clara de armazenamento de materiais para desdobramentos a posteriori.

No caso do anexo que se lhe segue — uma 'Memória sobre a possibilidade de descrever os sons e as articulações da voz dos animais' - , embora resultado direto dos sentidos e da experiência do viajante, por não terem sido as vozes animais registradas durante a expedição ficaram também, como tantas vezes depois enfatizaria Florence, na dependência da memória. Tecnicamente, pois, decidiu o viajante separar a descrição-narração da viagem científica, sempre vazada na experiência direta do deslocar-se, do descobrir e do conhecer in loco novas espécies animais, vegetais e novos agrupamentos de populações nativas ou sertanejas, das experiências indiretas advindas da audição, mas sobretudo da memória dessa audição. Se, para efeitos do relatório a ser encaminhado com urgência para a Academia de Ciências da Rússia, a solução dos anexos the pareceu adequada, anos mais tarde, quando a memória ocupou a cena principal de seu discurso, de certa forma os temas outrora 
anexados parecem ter assumido um lugar de destaque na sua trajetória singular de inventor, livre-pensador e principal narrador da expedição Langsdorff. Nas várias versões da Zoofonia, por exemplo, isso ficou mais do que evidente, pelo modo obsessivo com que retoma o tema (cf. Hardman, Kury, 2004).

Já em se tratando de Algumas histórias as pistas são mais escassas, mas indicam de todo modo, igualmente, a relevância e a preocupação que o autor lhes dedicava. Fixando-se principalmente na história 1 - a única que possui um título, 'Ingratidão e barbárie de dois brancos para com negros fugidos', e que ocupa, sozinha, quase $40 \%$ do manuscrito, sendo os $60 \%$ restantes distribuídos entre as outras seis histórias - , Hercule Florence retorna a ela, embora com alteração significativa de personagens e lugares, nas duas versões mais conhecidas da narrativa Viagem fluvial do rio Tietê ao Amazonas (1825-1829). Entre 1848-1859, época aproximada em que escreveu uma dessas variantes, encontramos a seguinte anotação (Florence, 1977a, s. p.):

Ainda nesse dia (14-jul.-1826) passamos pelo rio, ilha e cachoeira do Quilombo', lugar em que uma porção de negros, em outros tempos, se refugiaram, motivo de tal denominação. A infeliz raça, sem embargo de quererem os brasileiros fazer crer o contrário, parece não de todo resignada à escravidão, tanto que os pobres negros tiveram a coragem de embrenhar-se pelas matas, expostos às feras, como a onça, e à ferocidade dos indígenas, que, não os considerando criaturas humanas, se mostram ainda mais impiedosos com eles do que com os brancos. $\mathrm{O}$ triste contraste é que, se os negros amam a liberdade, seus civilizados senhores os excedem, em muito, na avidez de seu suor e de tudo o mais que deles podem arrancar. Pois bem: ao voltarem de Cuiabá, negociantes sempre em viagem descobriram o Quilombo, asilo dos negros fugidos; era bem mais do que se necessitava para aguçar a cupidez, de modo que de Porto Feliz partiu expedição para pô-los a ferros e, assim, mais de cento e vinte desses desgraçados, presos pelo pescoço a correntes fixadas na proa e na popa de várias pirogas, retornaram ao local de seu anterior cativeiro..

Note-se que aqui são negociantes vindos de Cuiabá, e não soldados portugueses extraviados de uma guarnição da fronteira, como na história 1, os responsáveis pela descoberta do quilombo e a conseqüente expedição punitiva. Ao mesmo tempo, a localização do reduto dos quilombolas, de acordo com a rota da monção comandada por Langsdorff e a data precisa a que se refere o relato, ficava no sistema fluvial do rio Tietê, próximo ao salto de Avanhandava, atingido quatro dias depois, e a meio caminho entre Porto Feliz, de onde partiram três semanas antes, e sua desembocadura no rio Paraná, onde chegariam em quatro semanas mais. Em Algumas histórias, o quilombo situa-se às margens do rio Paranapanema, outro importante tributário da bacia do Paraná, área não atravessada 
pela expedição imperial russa. No entanto, estruturalmente, os dois relatos são muito próximos (sintético no livro, extenso no manuscrito). Mas em Viagem fluvial Florence marca com maior ênfase sua posição anti-escravista. Considerando o interregno entre os dois textos (de duas a três décadas, aproximadamente), pode-se entender a crítica mais acerbada do autor no relato tardio, em conjuntura dominada pela questão da escravidão.

Na segunda variante de Viagem fluvial, traduzida com liberdades pelo visconde de Taunay e elaborada posteriormente, no intervalo aproximado entre 1860 e 1875, ressurge a referência, de novo modificada, ao mesmo relato. Vale a pena cotejá-la, porque o próprio autor esclarece a duplicidade entre essas histórias de quilombos:

No dia 14, passamos pela embocadura do rio 'Quilombo' e, pouco abaixo, pela ilha e cachoeira do mesmo nome. Ali se haviam antigamente refugiado muitos negros, pois 'quilombo' é palavra que designa o asilo onde eles se reúnem nas matas. Foram descobertos por negociantes que voltavam de Cuiabá e que, apenas chegados a Porto Feliz, armaram, por espírito de ganância, uma expedição com a qual atacaram aqueles infelizes, aprisionando mais de cento e vinte. Amontoados em canoas, voltaram os mal-aventurados aos pontos em que sofriam o cativeiro. 'Foi-nos o fato contado pelo guia. Em Porto Feliz haviam-me narrado outro tão semelhante que se pudera crer ser o mesmo; mas esse quilombo estava junto ao Paranapanema que corre para N.O. pelo país dos Xavantes. Contarei esta história no fim do diário. Talvez sejam com efeito dois sucessos diferentes um do outro' (Florence, 1977b, pp. 42-3; aspas simples nossas).

Este é um dos dois raros momentos de Viagem fluvial que registram referência direta a Algumas histórias. ${ }^{4}$ A outra passagem, feita na mesma variante e reportada poucas páginas antes, é inserida em um comentário sobre os vastos e inexplorados sertões que se situavam entre Curitiba e as margens ocidentais dos leitos dos rios Tietê e Paraná até as Sete Quedas, quando então Florence (ibidem, p. 38) anota:

[esta vasta zona de terreno é um] país que não foi explorado se não por uma expedição, a qual subiu algumas léguas pelo Paranapanema acima, na procura de negros quilombolas. 'Contarei no fim deste diário de que modo descobriu-se o valhacouto desses negros na margem de rio tão distante e pouco conhecido. A narração é interessante '(aspas simples nossas).

Além das diferenças já notadas quanto a localização geográfica e certos personagens, Florence explicita aqui uma outra, fundamental para a questão da singularidade e veracidade do discurso histórico: a das fontes orais desses dois relatos. A história do quilombo do Tietê teve origem em narrativa de um dos guias da monção 
Langsdorff. 5 Trata-se, com quase toda a certeza, do veterano guia Antônio Lopes, que havia acompanhado, durante 40 anos, 26 monções na rota Porto Feliz-Cuiabá. Langsdorff (ibidem, p. 246) tece vários elogios a ele em seu diário, registrando, por exemplo:

Antônio Lopes, nosso guia, tem sua memória extraordinária; conhece cada pedra da cachoeira, cada árvore frutífera às margens do rio, cada banhado ou riacho, cada relva, cada acontecimento, cada quebra, naufrágio ou perda de embarcações ou homens, escravos ou livres, no caminho de Porto Feliz até Cuiabá.

Já o relato da história 1 do manuscrito, como se depreende de sua leitura, deve-se a dois depoentes, ambos habitantes de Porto Feliz, mas membros de grupos sociais e étnicos opostos: o cirurgiãomor e futuro sogro de Florence, Francisco Álvares Machado e Vasconcellos ${ }^{6}$, e um velho negro e ex-morador do quilombo, testemunha ocular e vítima da expedição.

A questão das fontes orais é das mais interessantes em torno do documento aqui publicado e, por extensão, da própria memória histórica que se acumulou ao longo da expedição Langsdorff. Sabese que os viajantes sempre se valeram de diversos informantes locais. Na ausência de critérios mais objetivos para a análise seletiva e comparativa dos relatos ouvidos e anotados, pelas dificuldades naturais impostas ao deslocamento em áreas inóspitas e mesmo pela escassez de fontes plurais, o expedicionário valia-se muitas vezes de testemunhos únicos, dependente da habilidade oratória de narradores especiais que passavam a deter, com exclusividade, o dom da persuasão, de convencer seus ouvintes e obter sua confiança. De modo similar ao da literatura romântica de ficção, as narrativas de viagem estão repletas desses 'contadores de casos'. Em seus relatos misturam-se inevitavelmente eventos históricos, mitos, lendas, memórias de famílias ou de outros grupos sociais específicos, lapsos e inventos próprios à arte de narrar. Isso só faz aumentar o valor historiográfico da literatura dos viajantes como repositório da memória popular e de antigas tradições orais.

É, pois, inescapável, que as anecdotes de Florence, assim como casos incorporados às duas variantes de Viagem fluvial e muitos dos informes e das histórias registrados nos diários de Langsdorff, possuam essa natureza ambígua entre o histórico e o fictício. No caso deste último são bom exemplo as narrativas ouvidas sobre proezas formidáveis envolvendo onças e sucuris, na velha tradição das histórias de caçadores, trazidas pelo guia Lopes ou por Francisco Álvares (cf. Langsdorff, op. cit., pp. 121-2, 148-9). Com relação a este aspecto, a história 7 das anecdotes oferece-nos um exemplo bem ilustrativo. Em um curto relato de cerca de 13 linhas, Florence justapõe, na mesma figura de "um desses sertanistas", a lendária 
história do bandeirante Bartolomeu Bueno da Silva, o Anhangüera (Diabo Velho), que, tendo atingido os sertões goianos, em 1682, teria se valido do estratagema de pôr fogo à aguardente para alcançar ascendência junto aos indígenas; de seu filho homônimo, que reproduz, a partir de 1722, o itinerário do pai (que acompanhara ainda criança), chegando à fundação, em 1726, do arraial originário da futura Vila Boa de Goiás, depois de ter localizado as primeiras jazidas de ouro na região, sempre com ajuda dos índios; e, finalmente, dos sertanistas Teodósio Nobre, Ângelo Preto e Antônio de Pinho Azevedo, entre outros, que, em 1736, tinham completado a abertura do caminho por terra, através de picada de cem léguas, entre os dois novos eldorados brasileiros: Vila Boa de Goiás e Cuiabá.7

Mas outro detalhe nas referências de Florence ao "quilombo esquecido" revela-se aqui da maior importância. O autor anuncia, nas duas passagens acima citadas, sua intenção de incorporar pelo menos a história 1, senão as demais narrativas do manuscrito Algumas histórias, ao fim daquela versão de Viagem fluvial, mantendo a propósito, inclusive, certo suspense na expectativa do leitor: "Contarei esta história no fim do diário. Talvez sejam com efeito dois sucessos diferentes um do outro." Ou antes: "Contarei no fim deste diário de que modo descobriu-se o valhacouto desses negros na margem de rio tão distante e pouco conhecido. A narração é interessante.” O que, efetivamente, não ocorreu, podendo-se imaginar como possíveis razões: o espaço limitado da revista do IHGB, onde pela primeira vez o visconde de Taunay publica Viagem fluvial (1875-76); e, principalmente, o tempo exíguo entre os envios da versão final por Florence, a livre tradução do visconde e a impressão da revista (sabe-se, por exemplo, que a última parte, datada do segundo semestre de 1876, somente sairia depois de abril de 1877 — cf. Hardman, Kury, op. cit., cap. 1).

Interessante imaginar também que se Florence, falecido em 1879, tivesse conseguido incorporar, ao final da Viagem fluvial, esta ou outras das narrativas de Algumas histórias, o destino de sua recepção teria sido diverso. Para além do relato da expedição Langsdorff, o antigo anexo de seu relatório à Academia de Ciências da Rússia de 1829-30 teria, ao adentrar a narrativa principal, oferecido nova perspectiva ao conjunto da obra, como crítica de costumes e análise histórico-cultural da sociedade colonial brasileira, centrada no tema da violência e da barbárie nos interiores do país, nos sertões atravessados décadas antes pela expedição Langsdorff, ali onde eram mais tênues os laços societários fundados na lei e no Estado. Em uma palavra, Florence esboça em Algumas histórias, por trás, muita vez, da extrema brevidade do registro e da narrativa simples, quase minimalista, a crítica da precariedade da organização da sociedade nacional nos confins da civilização, ao inaugurar-se a autonomia político- 
administrativa do Brasil. O viajante deixa claro o cenário priorizado nessas anecdotes brésiliennes: não o litoral nem a cidade, mas a zona rural, os roteiros das entradas e monções — o sertão. Tema que depois, já em começos do século XX, encontraria vários intérpretes em nossa historiografia (cf., entre outros, Abreu, 1963).

Mas podemos especular igualmente em torno da hipótese de que Florence não retomou Algumas histórias ao final de sua Viagem fluvial porque desejava publicá-las todas, e talvez considerasse necessário reescrevê-las, especialmente os seis esquetes sumários que constituem as histórias de número 2 a 7. Se isso acaba por nelas favorecer a reprodução de alguns estereótipos comuns à sociedade e à ideologia no Brasil da época - entre eles a visão dos índios entre ferozes e crédulos, o mulato mau-caráter, o negro bom e fiel, o padre libertino, a mulher traidora, o sertanista sagaz, o campônio desconfiado, figurações que pouco mais tarde alimentariam muitos dos tipos presentes em parte da literatura romântica de ficção entre nós , é verdade que, por outro lado, o caráter breve de alguns relatos produz um efeito de maior contundência na manifestação do motivo que perpassa todas essas Algumas histórias: a violência das relações sociais.

Em um caso extremo, aquele da narrativa mais concisa da série, a da história 3, toda ela escrita no tempo presente, quase sem entrecho, em menos de dez linhas, em que dois caçadores surpreendem, na mata, dois homens esfolando vivo um terceiro, e o drama se resolve com a morte de três personagens (a vítima, um dos torturadores e um caçador que tenta socorrer o agredido), não ficamos sabendo das razões que levaram àquela "abominável torpeza" ou "épouvantable scélératesse", mas parece que isso pouco importa afinal, pois é a condição monstruosa das relações humanas que deve ser ressaltada. A ausência de nomes em todos os relatos também reforça esse efeito de gratuidade da violência e do engano recíproco entre os habitantes e membros de segmentos sociais díspares. Só sabemos que a história se passou em São Paulo (quiséramos crer no interior distante da província, mas nem isso o relato esclarece poderia tratar-se de mata nas cercanias da capital).

Comparável pelo excesso de violência concentrada nas relações sociais e familiares, o diário de Langsdorff (op. cit., pp. 122-3) relata esta outra história, que teria sido contada por Francisco Álvares, no barco do comandante, já nos primeiros dias da monção:

História do rapaz que vingou seu irmão e cometeu sete assassinatos: um jovem visitava uma jovem à noite; o irmão dela, sentindo-se ofendido, arquitetou, junto com seis amigos, um plano para o vigiarem. Eles o encontraram conversando, à janela, com a jovem. Bateram nele, o esfolaram vivo e mandaram entregar o corpo à jovem e à mãe. Esta, revoltada com tanta crueldade, mandou chamar 
um de seus filhos e mandou-o vingar a morte do irmão. Deu-lhe alguma coisa e trancou a casa. Todos os assassinos, que o jovem conhecia, tinham fugido. Garcia partiu, viajou por quase todo o Brasil e, depois de muitos anos, após haver executado a sua missão, voltou e entregou à mãe as 14 orelhas dos assassinos de seu irmão.

Sugerindo que a brutalidade incorporada à formação social brasileira desde a colônia e alicerçada, entre outras coisas, no escravismo e no massacre de índios havia se disseminado nos mais diversos meios, incluindo a repressão sexual, a opressão das mulheres e o peso da igreja inquisitorial — "Que país! Que brutalidade! Quanto falta aqui ainda para serem chamados de civilizados!", reclama Langsdorff (ibidem, p. 278) a certa altura —, o chefe da monção reitera o registro de cenas de atrocidade familiar:

Hoje [05-mai.-1826], uma pessoa bastante confiável contou-nos uma história escabrosa que aconteceu há alguns anos, em Itu. Num domingo, um padre, caminhando depois da missa, viu sua sobrinha observando, curiosa e sem o conhecimento da mãe, através da janela de grade, as pessoas que passavam. O tio foi ter com sua irmã para repreendê-la por estar se descuidando da educação da filha, que, segundo ele, observava furtivamente os transeuntes. À tarde, a irmã mandou chamar seu irmão, que, a essa altura, já estava de novo em casa, e mostrou-lhe o cadáver da filha, que ela havia estrangulado, garantindo-lhe que, a partir dali, ela não olharia mais as pessoas na rua (idem, ibidem, pp. 85-6).

Como em Florence, o caráter conciso da anotação aumenta o efeito do choque provocado pela irrupção de violência tão descomunal quanto injusta. Voltando ao manuscrito das anecdotes, se muitas vezes o esquematismo do registro pôde favorecer o clichê, há outras características no texto — que jamais deveria ser lido fora de sua contextualização, como material resultante do inventário da natureza e da sociedade brasileira produzido pela expedição Langsdorff - a sugerir o acurado espírito crítico de Florence, seu cuidado com o uso preciso do léxico local e sua repulsa à violência e à desigualdade social. Ao esboçar o desenho de 'quadros' dessa paisagem humana dominada por histórias de barbárie, o autor tangencia a questão da historicidade dos eventos narrados (a um só tempo natural e social). O quilombo é visto positivamente, como lugar de afirmação de uma comunidade liberta da escravidão que compartilha os frutos do trabalho e adota religião sem clérigos. Os algozes que organizam a expedição punitiva são levados a ela por cupidez e desejo de lucro. A idéia de uma 'nação brasileira' oscila na instabilidade da violência gratuita (cujo maior signo é o escravismo) e do território imenso ainda não constituído em Estado nacional, mas habitado por populações quase incomunicáveis: índios ${ }^{8}$, sertanistas, camponeses, quilombolas, soldados dispersos 
etc.; estes últimos, curiosamente chamados de "portugueses" no início da história 1 e, depois, respectivamente, de "estrangeiros" em relação aos negros do quilombo e de "brasileiros" em relação ao desejo de "rever o país natal", identificado não com Portugal mas simplesmente com o regresso a Porto Feliz. Isso sugere fronteiras fugazes, entre pequenas localidades relativamente isoladas e imensos sertões inóspitos, e identidades sociais, raciais e lingüísticas igualmente instáveis, a exemplo do que sucede na história 7, quando a "língua geral", ou "língua brasileira", de base tupi, é o idioma comum e viável para o diálogo entre o sertanista e os índios que lhe barram o caminho.

Florence preferiu "pirogas" a canoas para falar das embarcações mais rudimentares dos negros fugidos, próximas material e semanticamente dos barcos indígenas tradicionais. Referiu-se acertadamente a "sertanistas" como sinônimo dos bandeirantes que desbravaram os caminhos por terra às minas do Centro-Oeste. Sua dicotomia civilização versus barbárie é certamente tributária dos filósofos e ideólogos das Luzes. O desenraizamento de experiências sociais limítrofes ainda parece ser a tônica nesse Brasil, onde "terra natal" pode significar não o império recém-instituído, mas locais que vão do quilombo comunitário a diferentes porções do território, de povoados a sertões, de caminhos a vilas, de rios a minas, de matas a chapadas. E a paisagem, nesses confins da civilização, é bastante inóspita e marcada por violência, não fundadora mas disseminada. Como o quilombo que se embrenha na floresta, fugindo de seus perseguidores, é como se o quadro todo da sociedade nacional nascente apontasse para aquela imagem caótica entre "cinzas e solidão".

Assim, reinseridas na memória da expedição Langsdorff e na experiência dos sertões, as apenas esboçadas Algumas histórias de Florence são o contraponto do relato principal da viagem fluvial, diário pautado pelo percurso realizado pelos viajantes. As cenas narradas nas anecdotes pretendiam dar início a uma espécie de inventário dos costumes em uso nos sertões brasileiros. Por tradição, a arte de viajar filosoficamente incluía a apresentação das características físicas dos lugares, a coleta e a classificação dos objetos de história natural e a descrição dos costumes das populações encontradas. O relato de viagem manteve, ao longo do século XIX, a pretensão de tratar globalmente das sociedades e dos espaços visitados, entremeando na narrativa organizada em função do encadeamento cronológico e do deslocamento espacial, seguindo o dia-a-dia da expedição, pequenas memórias monográficas sobre algum tema julgado digno de atenção pormenorizada.

A viagem ao Oriente do grande mestre do moderno método de viajar de forma útil, o ideólogo Volney, é considerada como modelo durante o alto Iluminismo e boa parte do século XIX. Pregando ao 
mesmo tempo um distanciamento do objeto que favoreça a objetividade, Volney aconselha também a imersão no ambiente estudado. Diz o ideólogo (Volney, 1959, p. 399):

De todos os objetos de observação que pode apresentar um país, o mais importante, sem contestação, é a moral dos homens que o habitam; mas é preciso confessar também que ele é o mais difícil: pois não se trata de um estéril exame dos fatos; o objetivo é apreender suas relações e suas causas, descobrir suas forças motrizes aparentes ou secretas, distantes ou próximas, que nos homens produzem esses hábitos de ações que chamamos de costumes, e essa disposição constante do espírito a qual nomeamos caráter ...

Florence não tinha formação acadêmica em nenhum ramo das artes ou das ciências. Suas aptidões foram desenvolvidas de maneira autônoma. Apesar disso, ele parecia estar familiarizado com os procedimentos gerais da arte de viajar. O corpus composto pelo relatório da viagem, a memória sobre as vozes dos animais e Algumas bistórias formam um conjunto coerente, no sentido de traçar paisagens das regiões visitadas que não se limitam ao mundo natural como objeto, nem ao olhar como sentido. Paisagens naturais, sonoras e humanas - eis o traçado de Florence. Mais ainda: ele pretendia, como indicavam os viajantes-filósofos, estabelecer conexões entre os diversos fenômenos. Esta tentativa de síntese fica perceptível no relatório e nas demais versões da viagem, em que por diversas vezes o viajante buscou esboçar um quadro geral do que via. Um bom exemplo disso é a passagem do Continuation de l'esquisse..., sobre a cidade de Cuiabá, onde descreve as linhas gerais do que seria o caráter predominante da população da região, em oposição às disposições dos habitantes de cidades litorâneas. Segundo o viajante, em Cuiabá,

É-se muito apaixonado pela vingança; não por aquela que se dá em face do inimigo. Se eles atacam, é traiçoeiramente. Conheci dentre os jovens que freqüentei e que tinham boas qualidades, que seu orgulho era determinar-se a matar ou intimidar seus inimigos de qualquer maneira. Porém, devo dizer a favor da juventude brasileira que aqueles que conheci em Cuiabá e que eram do Rio de Janeiro e outros lugares marítimos não pensavam assim (Florence, 1829-1830a, s. p.).

Neste trecho, Florence delineia uma espécie de tipologia dos caracteres brasileiros do sertão. Anos depois, ao reescrever suas aventuras na expedição Langsdorff, o viajante desenvolve com mais vagar os múltiplos aspectos que envolvem a descrição dos costumes do interior. Do mesmo modo, nenhuma das sete anecdotes se passa 


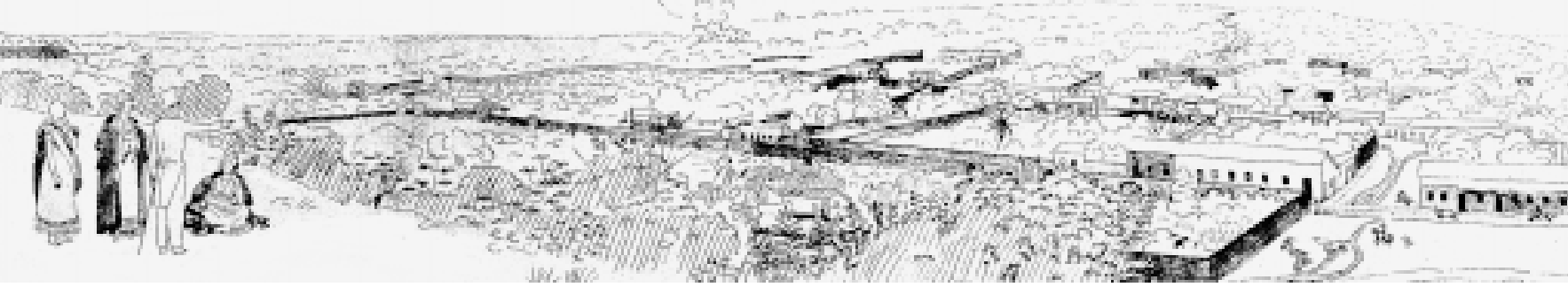

Vista da cidade de Cuiabá, desenho de Hercule Florence (s. d. [1827?]).

no litoral. Em versão da viagem redigida entre 1848 e 1859, novamente sobre Cuiabá, insere o excurso 'Descrição de Cuiabá. Costumes locais', em que procura elencar um conjunto de fatores que concorrem para distinguir a fisionomia da região. Ele introduz o tema de forma clássica: uma descrição física da cidade. Em seguida lembra-se de quando ainda estava em Mônaco, esperando algum navio que o levasse para a zona tórrida. No interior do Brasil mudara inteiramente de situação: "Do rochedo de Mônaco, trasladei-me para Cuiabá, cidade cercada de ilimitados desertos, que a separam do mundo quase que do próprio Brasil, cidade situada em plena América do Sul, tão distante do Atlântico e do mar austral, quanto do Panamá e do cabo Horn" (Florence, 1977a, s. p.).

Esclarecido o contexto geográfico, o viajante introduz mais um elemento: a composição heterogênea da população, formada inicialmente pelos paulistas, "na qual reinam as leis, os costumes, as superstições, os hábitos, os vícios e as virtudes dos portugueses, dos mouros, dos brasileiros, dos selvagens e dos negros da África" (idem, ibidem, s.p.). Tal contexto, aliado aos "ardores do clima", moldava um quadro de costumes desenfreados e de luxúria jamais testemunhados por ele em nenhum outro lugar: padres que vivem em concubinagem, casais amancebados, mulheres que traem seus maridos, grande número de prostitutas. Mas, dando continuidade à sua tentativa de compreender este traço moral, Florence desenvolve ainda mais sua argumentação em favor das causas culturais do fenômeno. Segundo ele, elemento importante a considerar é o isolamento da população com relação aos preceitos religiosos e às normas da civilização, únicos freios capazes de ocupar moralmente pessoas que não precisam trabalhar com afinco para viver em clima fértil. Além disso, há a corrupção causada pela escravidão e a proximidade dos índios "cuja liberdade, inocente nas matas, se metamorfoseia em vício, quando usada por povo que pretende passar por civilizado" (idem, ibidem, s. p.).

Um último elemento é evocado para explicar o comportamento desses brasileiros: a história da ocupação dos sertões em função da 


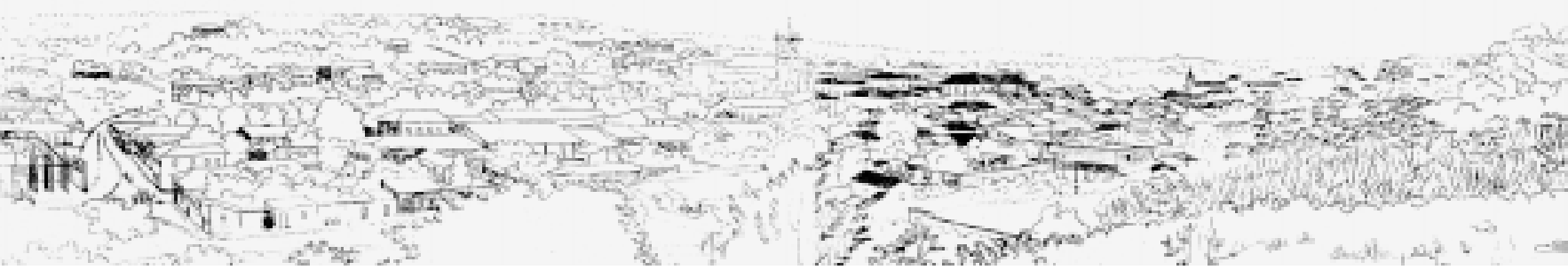

Reprodução da Viagem fluvial do Tietê ao amazonas de 1825 a 1829 (São Paulo, Melhoramentos, 1941).

mineração. Para Florence, a chegada à região de paulistas "ávidos de ouro" proporcionou o acelerado crescimento populacional, mas, como todos só pensassem na extração do metal precioso, a agricultura foi negligenciada e os alimentos tornaram-se caríssimos. Daí resultou o povoamento por indivíduos afastados da religião e de normas disciplinadoras, e "a maior parcela dos caracterizadamente aventureiros, sedentos de grossas maquias, não encontrando à vontade ouro em condições de saciar, lançou mão de toda espécie de violências: roubo, assassinato, sangrentas rixas haviam já principiado a arruinar a nascente colônia ... (idem, ibidem, s. p.).

Esta visão aterradora da região de Cuiabá, dominada pela mineração", encontra paralelo em Algumas histórias brasileiras, na qual pelo menos duas anecdotes, a 4 e a 7 , podem se passar em região de extração mineral. Na época em que escreve Viagem fluvial, Florence julga que a fase mais bárbara da colonização desses sertões já faz quase que totalmente parte do passado, ainda que muito recente. Ele parece acreditar que, com a diminuição da mineração e com o incremento da agricultura e das rotas de escoamento da produção, o interior brasileiro pudesse enveredar pelas sendas do progresso. O viajante chega a evocar os muitos mulatos letrados que encontrou, conhecedores de "Voltaire, Rousseau, Volney"; quem sabe futuros revolucionários, que, a exemplo de São Domingos, dariam fim à escravidão.

Dos esboços delineados em seu relatório enviado a São Petersburgo à narrativa da viagem redigida décadas mais tarde, o viajante aprimorou sua percepção da sociedade brasileira, tornando-se mais perspicaz ao elencar fatores relevantes e aprofundando sua crítica da escravidão e da monarquia. Nas anecdotes o elemento fundador da sociedade é a violência. Porém, cada vez mais um entusiasta de Charles Fourier, Florence busca nos mesmos sertões exemplos de solidariedade, de cooperação no trabalho e de alternativas comunitárias à propriedade privada. Que a publicação de Algumas histórias brasileiras sirva de convite ao leitor para prosseguir com o viajante por outras páginas que escreveu. 
FRANCISCO FOOT HARDMAN E LORELAI KURY

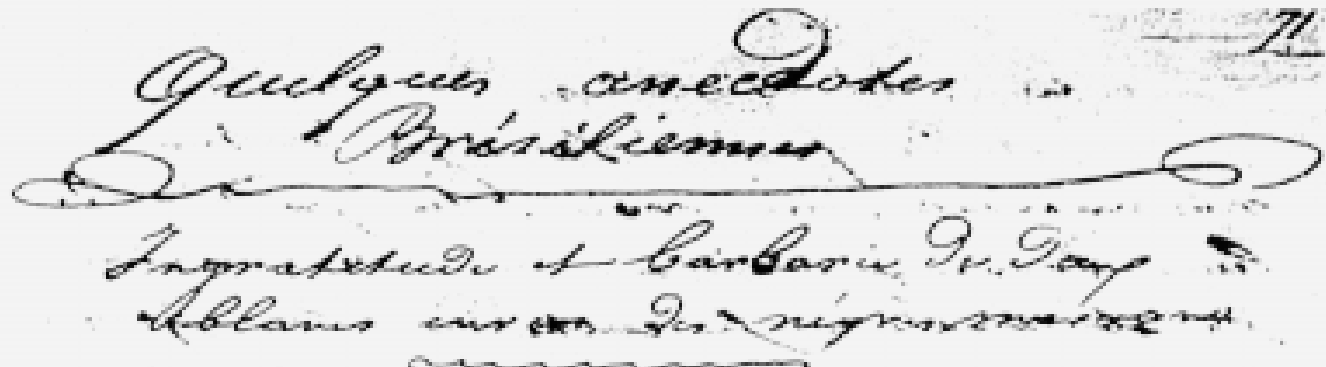

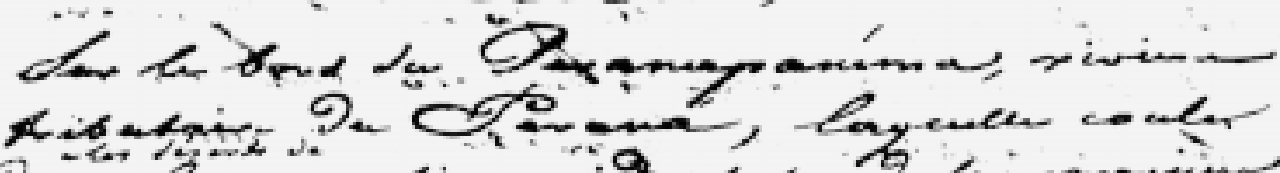
6)

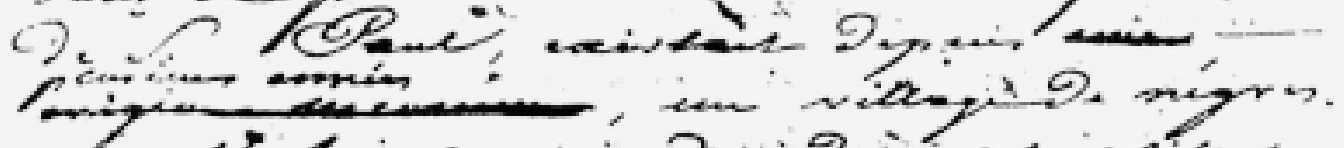

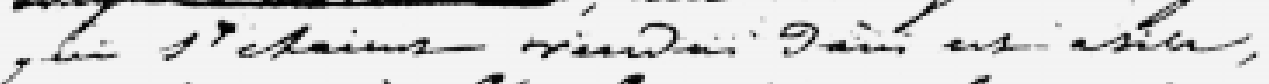

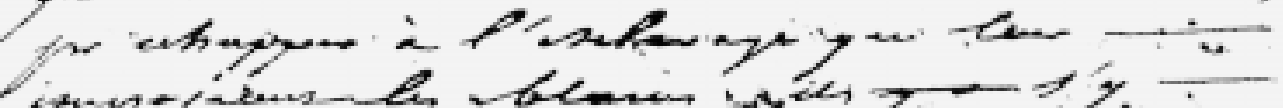

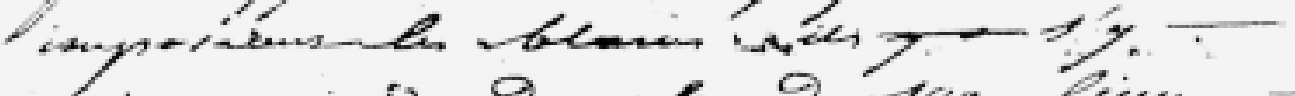

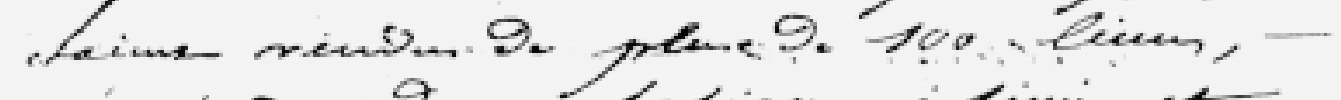

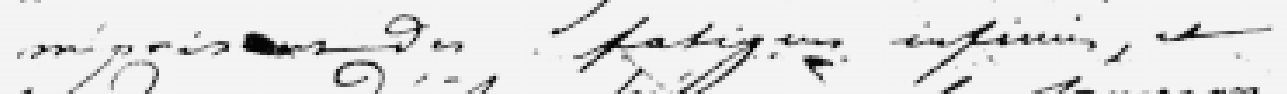

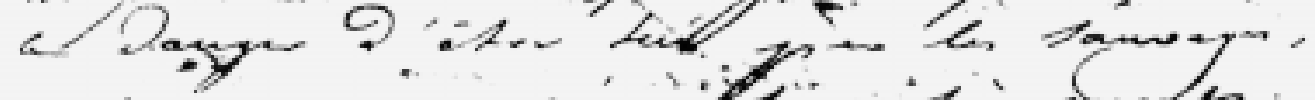

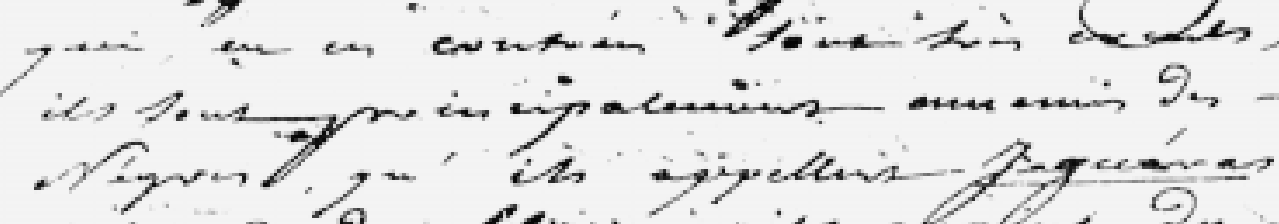

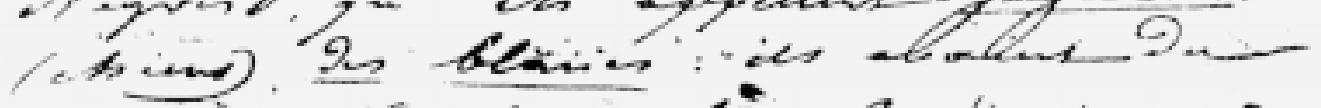
$\angle$ anm

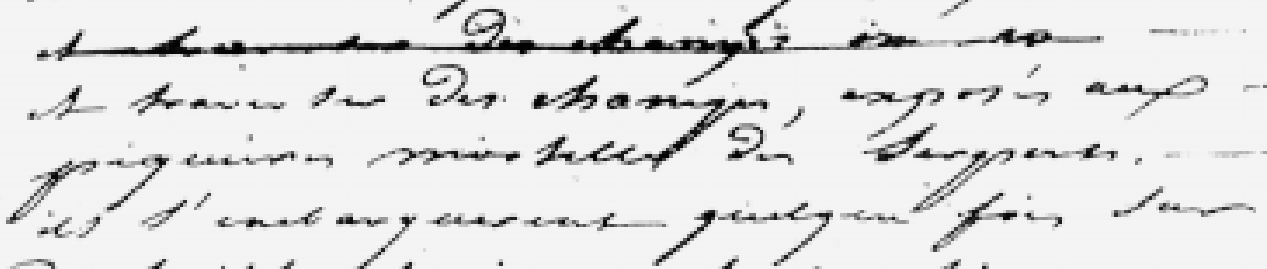

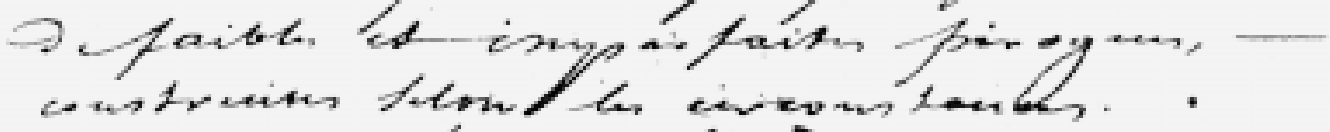

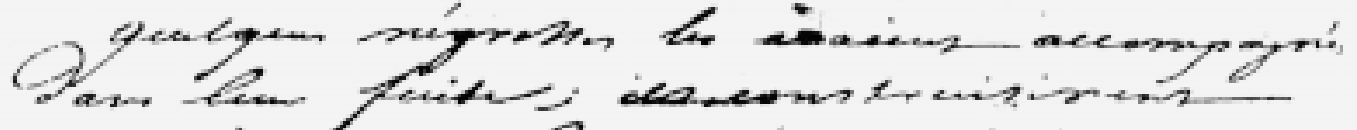

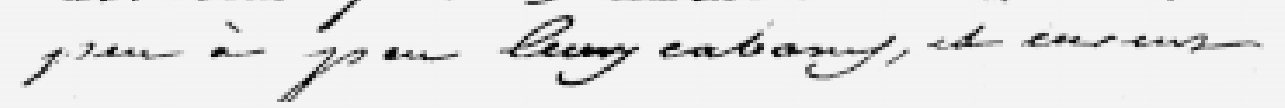

Cópia fac-similar de uma página do original

398

História, Ciências, Saúde — Manguinhos, Rio de Janeiro 


\section{Quelques anecdotes brésiliennes ${ }^{10}$}

Hercule Florence

\author{
Ingratitude et barbarie de deux blancs \\ envers des nègres marrons
}

\begin{abstract}
ur le bord du Paranapanema, rivière $\checkmark$ tributaire du Paraná, laquelle coule dans les deserts de la partie occidentale de la province de S. Paul, existait depuis plusieurs années un village de nègres qui s'étaient rendus dans cet asile, pour échapper à l'esclavage que leur imposaient les blancs. Ils s'y étaient rendus de plus de 100 lieus, méprisant des fatigues infinies, et le danger d'être tués par les sauvages, qui en ces contrées sont très cruels; ils sont principalement ennemis des nègres, qu'ils appellent \aguáras (chiens) des blancs: ils avaient du traverser les forêts les plus épaisses, et traverser des champs, exposés aux piqûres mortelles des serpents. Ils s'embarquèrent quelque fois sur de faibles et imparfaites pirogues, construites selon les circonstances.

Quelques negrèsses les avaient accompagnés dans leur fuite ; ils construisirent peu à peu leurs cabanes, et eurent
\end{abstract}

\section{f1. $71 \mathrm{v}$}

des enfants: ils vivaient de chasse, de pêche, et de fruits sauvages. Ils se nommèrent un roi : les produits de leur travaux étaient en commun. Ils observaient le culte des Portugais, et fesaient tous les jours la prière. Il y en eut un qui voulut exercer la fonction de prêtre ; il voulait toujours prêcher ; d'abord on l'écouta, ensuite on se moqua de lui.

Déjà plusieurs années s'étaient écoulées, et des nègres nés en cette retraite avaient des enfants, lorsque leur malhereux sort conduisit deux jeunes portugais parmi eux.

Ils étaient soldats, et avaient fait partie de la garnison du fort de Guaytimirim, sur la frontière des possessions espagnoles. Cette place, longtemps assiégée par les Espagnols avait du se rendre ; mais ces deux jeunes gens ne voulant pas être prisoniers, s'étaient enfuis sur une pirogue ; et, suivant le cours de la petite rivière qui mouille les murs du fort, ils la descendirent jusqu'au Paraná : comme ils cherchaient l'embouchure du Tiété

\section{Algumas histórias brasileiras ${ }^{11}$}

\author{
Hercule Florence
}

\author{
[1] Ingratidão e barbárie de dois brancos \\ para com negros fugidos ${ }^{12}$
}

\begin{abstract}
A s margens do Paranapanema, afluente do Paraná, que corre pelos desertos da parte ocidental da província de São Paulo, existia há vários anos um povoado de negros que se instalaram neste abrigo para fugir à escravidão que lhes impunham os brancos. ${ }^{13}$ Eles instalaram-se ali depois de mais de 100 léguas, ignorando fadigas infindas, e o perigo de serem mortos pelos selvagens, que nessas regiões são muito cruéis; e são principalmente inimigos dos negros, que chamam de jaguaras ${ }^{14}$ (cães) dos brancos. Tiveram que atravessar as mais espessas florestas e campos, expostos às picadas mortais das serpentes. Embarcavam às vezes em pirogas frágeis e imperfeitas, construídas conforme as circunstâncias.

Algumas negras acompanharam-nos em sua fuga; construíram pouco a pouco suas cabanas e tiveram
\end{abstract}

\section{fI. $71 v$}

filhos: viviam da caça, da pesca e de frutos silvestres. Eles nomearam um rei: os produtos de seus trabalhos eram da comunidade. Seguiam o culto dos portugueses e praticavam a reza todos os dias. Houve um deles que quis exercer a função de padre; queria pregar sempre; de início, foi ouvido, depois ridicularizado.

Muitos anos tinham transcorrido, e os negros nascidos neste refúgio já tinham filhos, quando sua má sorte levou até eles dois jovens portugueses.

Eram soldados, e haviam feito parte da guarnição do forte de Guaytimirim ${ }^{15}$, na fronteira dos domínios espanhóis. Este local, sitiado por longo tempo pelos espanhóis, teve que se render; mas esses dois jovens, não desejando cair prisioneiros, tinham fugido numa piroga; e, seguindo o curso do riacho que banha os muros do forte, desceram-no até ao Paraná. Como buscavam a desembocadura do Tietê 


\section{fl. 72}

pour se rendre chez leurs concitoyens, ils entrèrent dans le Paranapanéma croyant que c'était le Tiété, et le remontèrent jusqu'à la retraite des nègres, où ils reconnurent leur erreur.

D'abord ils furent aperçus par deux jeunes nègres qui furent au village dire qu'ils avaient vu deux étrangers à peu blanche et longue barbe (car les deux Portugais ne l'avaient pas faites depuis leur fuite) et qui avaient des vêtements ; l'alarme fut générale ; on craignit d'être découvert; quelques uns s'enfuirent dans les bois ; d'autres s'armèrent d'arcs, de flèches, de bâtons, et de quelques instruments en fer qui avaient été apportés par les premiers nègres qui avaient fui de chez les blancs. Cependant les deux Portugais remontèrent jusqu'au village, ne pensant pas qu'ils étaient au milieu des nègres ; ceux-ci les voyant venir seuls, à moitié nuds et sans armes, furent leur parler : quand ils surent pourquoi ils étaient venus là, ils les conduisirent au Roi ; ils étaient entourés par le peuple un peu rassuré, principalement par les jeunes nègres qui voyaient des blancs pour la première fois. Les deux étrangers demandèrent qu'on leur fasse la grâce de les laisser retourner

\section{f1. $72 \mathrm{v}$}

chez eux, en promettant qu'il ne sortirai jamais de leur bouche le secret de l'existence du quilombo (c'est le nom que l'on donne à un rassemblement de nègres fugitifs dans les bois) mais le Roi et les vieux leur refusèrent ce qu'ils demandaient, persuadés qu'il était impossible que ces gens gardassent le secret. Ils savaient que les blancs ne s'arrêtent pas à garder une promesse à des nègres. Il y eut quelques nègres qui proposèrent de les tuer, mais le Roi et les anciens s'y opposèrent ; on les garda à vue. Peu à peu ils eurent plus de liberté, parce que, soit qu'ils se montrassent contents de leur sort, soit que les nègres se reposassent sur ce qu'ils n'avaient pas les moyens de s'évader, ils étaient plus tranquiles. Ils se marièrent avec de jeunes négresses et eurent des enfants; ce qui leur attira encore plus la confiance des nègres. Ils arrivèrent au point de ne plus garder aucune mesure de précaution avec eux.

Mais ce fut alors que l'espoir de revoir le pays natal se réveilla

\section{fl. 72}

para se encontrar com seus concidadãos, entraram pelo Paranapanema acreditando que era o Tietê, e o subiram até o refúgio dos negros, onde reconheceram seu erro.

Desde o primeiro instante foram notados por dois jovens negros que foram ao povoado dizer que tinham visto dois estrangeiros de pele branca e longa barba (pois os portugueses não a haviam feito desde sua fuga) e que vestiam uniformes; o alarme foi geral; temiam serem descobertos; alguns refugiaram-se na mata; outros armaram-se de arcos, de flechas, de bastões e de alguns instrumentos de ferro que haviam sido trazidos pelos primeiros negros fugidos dos brancos. No entanto, os dois portugueses subiram até ao povoado, não imaginando que estariam cercados de negros; estes, vendo-os chegar sós, em farrapos e sem armas, foram ter com eles. Quando souberam por que tinham chegado até lá, conduziram-nos ao Rei; os dois viram-se cercados pelo povo já um pouco mais seguro, principalmente pelos jovens negros que viam brancos pela primeira vez. Os dois estrangeiros pediram que se lhes fizesse a graça de os deixar retornar

\section{fl. 72v}

para os seus, prometendo que jamais sairia de suas bocas o segredo da existência do quilombo (é o nome que se dá a um agrupamento de negros fugitivos nas matas), mas o Rei e os velhos recusaram-lhes a demanda, persuadidos de que era impossível que essa gente guardasse segredo. Sabiam que brancos não se detêm a guardar promessa para negros. Houve alguns negros que propuseram matá-los, mas o Rei e os anciãos opuseram-se; mantiveram-nos detidos sob vigia. Pouco a pouco eles ganharam mais liberdade, porque, seja por se mostrarem contentes com sua sorte, seja pelos negros se fiarem de que eles não teriam meios para se evadir, estavam mais tranqüilos. Casaram-se com jovens negras e tiveram filhos; o que lhes cativou ainda mais a confiança dos negros. Estes chegaram ao ponto de não mais guardar nenhuma medida de precaução para com eles.

Mas foi assim então que a esperança de rever o país natal manifestou-se 


\section{fl. 73}

avec plus de force dans le coeur des deux Brésiliens : ils purent même séduire un jeune nègre en lui faisant de brillantes relations de leur pays, et après avoir préparé tout ce qui pouvait servir à leur long voyage ils laissèrent leurs femmes et enfants, sortirent du quilombo, disant qu'ils allaient à la pêche, et s'éloignèrent aussi vite que possible. Lorsqu'ils arrivèrent au Paraná, le jeune nègre, se répentant de ce qu'il avait fait, les quitta à leur insu, et retourna au village, qui n'était pas encore très éloigné. Ils s'en soucièrent peu, et après avoir surmonté pendant trois mois des peines infinies, ils arrivèrent à Porto Féliz.

Ils eurent la barbarie de racconter leur aventure : la nouvelle se répandit qu'il existait au Paranapanéma un quilombo de plus de 300 nègres, entre hommes, femmes et enfants. La cupidité exaspera les esprits : une foule d'aventuriers se réunirent à Porto Féliz : on prépara des canots, plus de 50 personnes s'embarquent, calculant

\section{f1. $73 \mathrm{v}$}

déjà le bénéfice de leur entreprise : ce n'est pas assez pour les deux délateurs d'avoir préparé le malheur de tant de créatures, ils s'embarquent aussi. Après deux mois, l'expédition arrive au lieu de sa destination, mais ils ne trouvent que des cendres et la solitude : les pauvres nègres s'étaient doutés de ce qui leur arriverait, ils avaient brulé leur village, et s'étaient enfoncés dans l'intérieur. Nos gens infatigables découvrirent leur nouvelle retraite ; ils tombèrent sur eux ; en tuèrent beaucoup qui fesaient résistance, et, chargeant de chaînes ceux qu'ils purent attraper vifs, ils les entassèrent dans leur canots, et retournèrent à Porto-Féliz, où ils les vendirent ; ainsi ces malheureux, qui n'avaient voulu que leur liberté, et qui ne fesaient aucun mal, revirent le séjour de leur esclavage, victimes de leur humanité et de leur trop de confiance.

Quand j'étais à Porto-Féliz, il existait encore un nègre déjà très

\section{fl. 73}

com mais força no coração dos dois brasileiros: eles conseguiram até seduzir um jovem negro fazendo-lhe atraentes relatos de seu país, e depois de haver preparado tudo que poderia servir à sua longa viagem, deixaram suas mulheres e crianças, saíram do quilombo, dizendo que iriam à pesca, e se afastaram o mais rápido possível. Logo que chegaram ao Paraná, o jovem negro, arrependendo-se do que havia feito, abandonou-os à sua revelia, e retornou ao povoado, que não estava ainda muito longe. Eles pouco se incomodaram com isso, e após suportarem durante três meses penas infindas, chegaram a Porto Feliz.

Eles cometeram a barbárie de contar sua aventura. A notícia se espalhou: que existia no Paranapanema um quilombo de mais de 300 negros, entre homens, mulheres e crianças. A cupidez exasperou os espíritos: uma multidão de aventureiros reuniu-se em Porto Feliz; prepararam-se as canoas, mais de 50 pessoas embarcam, calculando

\section{fl. $73 v$}

já o lucro de sua empresa. Não é o bastante para os dois delatores ter preparado a infelicidade de tantas criaturas, eles embarcam também. Após dois meses, a expedição chega ao lugar de seu destino, mas eles não encontram senão cinzas e solidão: os pobres negros pressentiram o que lhes ocorreria, incendiaram seu povoado, e se enfiaram interior adentro. Nossas gentes infatigáveis descobriram seu novo refúgio; caíram sobre eles; mataram muitos dos que ofereciam resistência, e, acorrentando aqueles que puderam agarrar vivos, amontoaram-nos nas canoas, e retornaram a Porto Feliz, onde os venderam. Assim esses infelizes, que almejaram somente sua liberdade, e que não fizeram nenhum mal, reviram o estado de sua escravidão, vítimas de sua humanidade e de seu excesso de confiança.

Quando eu estava em Porto Feliz, existia ainda um negro já muito 


\section{fl. 74}

vieux qui avait été de ce quilombo : il avait raconté cette histoire d'ailleurs très connue au Chirurgien Major de cette ville, de qui je la tiens. Le vieux nègre lui avait dit que lorsque les Portugais surprirent lui et les siens dans la nouvelle retraite, il monta sur un arbre où on ne l'avait pas aperçu ; mais que lorsqu'il vit garrotter tous ses compagnons et brûler les cabanes, voyant qu'il périrait s'il restait seul exposé aux onces et aux sauvages, il avait préféré l'esclavage à une mort certaine, et s'était montré aux Portugais.

Une femme de la campagne à Curitiba, Province de S. Paul, avait une intrigue amoureuse: elle et son amant, fatigués de l'incommodité que causait la présence du mari, resolvèrent de le tuer. La femme le conseilla de se rendre le soir avec l'obscurité dans le jardin, et de mettre les poules en épouvante, espérant que le mari irait voir ce que ce serait, et recevrait la mort. En effet, quand il fut nuit, on

\section{f1. $74 \mathrm{v}$}

entendit crier toutes les poules; la femme dit au mari d'aller voir ; celui-ci qui était fatigué des travaux de la campagne, ne voulut pour rien se lever de son hamac ; quand elle vit qu'elle insistait en vain, elle sortit pour avertir son amant de l'insouciance de son mari. En sortant elle reçoit un coup de fusil qui l'étend par terre, et qui n'a pas été tiré pour elle. Au bruit du coup, le mari prend son fusil qui était chargé, accourt, voit venir vers lui l'assassin, qui rencontre la mort là où il croyait rencontrer sa maîtresse. Les deux coupables survécurent quelques heures, et confessèrent leur crime.

Deux habitants de S. Paul chassaient dans un bois: ils entendent des gémissements étouffés; un d'eux veut absolumment voir ce que c'est; il s'avance doucement, et aperçoit deux hommes qui écorchent vif un malheureux qu'ils ont attaché à un arbre, et auquel ils avaient mis un bâillon dans la bouche: saisi d'horreur et

\section{fl. 74}

velho que havia sido deste quilombo: ele contou esta história, aliás muito conhecida, ao cirurgião-mor daquela cidade ${ }^{16}$, de quem eu a tenho. O velho negro disse-lhe que logo que os portugueses surpreenderam a ele e aos seus no novo refúgio, subiu numa árvore onde não foi visto; mas que quando viu amarrarem todos seus companheiros e queimarem as cabanas, vendo que morreria se permanecesse sozinho exposto às onças e aos selvagens, preferiu a escravidão a uma morte certa, e se revelou aos portugueses.

[2] Uma camponesa em Curitiba, província de São Paulo ${ }^{17}$, tinha uma intriga amorosa: ela e seu amante, cansados do incômodo causado pela presença do marido, resolveram matá-lo. A mulher aconselhou-o a se esconder, na obscuridade do crepúsculo, no quintal, e a espantar as galinhas, esperando que o marido iria ver o que se passava, e receberia a morte. Com efeito, quando se fez noite,

\section{fl. $74 v$}

ouviram-se as galinhas a gritar; a mulher diz ao marido que vá ver; este, que estava cansado dos trabalhos no campo, não quis se levantar de sua rede por nada; quando ela viu que insistia em vão, saiu para advertir seu amante da indiferença de seu marido. Ao sair, ela recebe um tiro de fuzil que a estende por terra, e que não se destinava a ela. Ao barulho do tiro, o marido toma seu fuzil que estava carregado, acorre, vê vir em sua direção o assassino, que encontra a morte no lugar em que acreditava encontrar sua amante. Os dois culpados sobreviveram algumas horas, e confessaram seu crime.

[3] Dois habitantes de São Paulo caçavam numa mata: eles ouvem gemidos sufocados; um deles quer de toda maneira ver o que é; ele avança lentamente, e avista dois homens que esfolam vivo um infeliz que amarraram a uma árvore, e ao qual haviam posto uma mordaça: tomado de horror e 


\section{fl. 75}

transporté d'indignation, il leur tire son coup de fusil, mais il a le malheur de ne pas blesser. Un de ces monstres, plonge subitement un poignard dans le coeur de sa victime, prend son fusil, et étend par terre le généreux agresseur; mais à son tour, il tombe d'un coup de fusil qu'il reçoit de l'autre chasseur: le compagnon de son épouvantable scélératesse s'enfuit.

Un homme de Minas Gerais partait pour un petit voyage: son nègre, qui n'était pas encore prêt, lui dit qu'il ne tarderait pas à le rejoindre. Peu de temps après il se mit en chemin, et étant arrivé à un certain endroit, il fis la remarque que les traces du cheval de son maître, lesquelles il connaissait très bien, indiquaient qu'il était entré dans le bois; il fut en même temps surpris de voir beaucoup d'empreintes de pieds de nègres, qui toutes designaient une sortie de ce bois: il fut un peu plus loin, et ne voyant plus rien, il sortit de route, retourna sur ses pas, et entra dans le bois. Il suivit les indices récents qu'il voyait soit sur les branches, soit sur les plantes, jusqu'à ce qu'il aperçut

\section{fl. $75 \mathrm{v}$}

d'un peu loin son maître amarré à un arbre, et entouré de nègres marrons qui allaient le faire mourir. Alors sans délibérer, il court à eux en criant: Oui, c'est bien fait, tuez ce blanc qui m'a tant fait souffrir; tuez-le, puissions-nous les tuer tous, ces blancs qui nous tyrannisent. Et s'adressant à son maître, il lui dit: Eh bien, c'est à présent que tu vas me payer les coups que tu m'as donné; c'est moi même que veux te tuer! Fais ton acte de contrition, c'est la dernière heure! Mes camerades, donnez-moi le fusil, mettez-vous tous là, vous allez voir comme je vais le tuer! Il prend vite le fusil, réunit les nègres de côté, vise sur son maître; détourne le fusil et lâche le coup sur les nègres ; il se jette au milieu d'eux et avec de prompts et vigoureux coups de crosse, les disperse. Il coupe promptement les liens de son maître, le fait monter à cheval, en lui disant de s'éloigner bien vite. Il s'éloigne aussi, mais en bonne contenance. De cette manière il

\section{fl. 75}

levado pela indignação, atira neles com seu fuzil, mas tem o azar de não feri-los. Um desses monstros crava subitamente um punhal no coração de sua vítima, toma seu fuzil, e estende por terra o generoso agressor; mas cai por sua vez, sob um tiro de fuzil que recebe do outro caçador. O companheiro de sua abominável torpeza foge.

[4] Um homem de Minas Gerais partia para uma pequena viagem: seu negro, que não estava ainda pronto, disse-lhe que não tardaria a alcançá-lo. Pouco tempo depois, este se pôs a caminho, e tendo chegado a um certo lugar, notou que os rastros do cavalo de seu senhor, os quais conhecia muito bem, indicavam que entrara na mata; ao mesmo tempo, ficou surpreendido ao ver muitas pegadas de pés de negros que assinalavam uma saída dessa mata. Ele foi um pouco mais longe e não vendo mais nada, saiu da estrada, retrocedeu e entrou na mata. Seguiu os vestígios recentes que via, seja nos galhos, seja nas plantas, até que avistou

\section{fl. $75 v$}

a certa distância seu senhor amarrado a uma árvore, e cercado de negros fugidos que iam fazê-lo morrer. Então, sem pensar, correu até eles gritando: Sim, bem feito, matem este branco que tanto me fez sofrer; matem-no, pudéssemos nós matá-los a todos, esses brancos que nos tiranizam. E dirigindo-se a seu senhor, disse-lhe: Ah, bom, é agora que tu vais me pagar as surras que tu me destes; eu mesmo quero te matar! Faça teu ato de contrição, chegou a hora derradeira! Meus camaradas, passem-me o fuzil, ponham-se todos lá, vocês verão como eu vou matá-lo! Toma rápido o fuzil, reúne os negros de lado, faz mira na direção do seu senhor; desvia o fuzil e atira sobre os negros; lança-se ao meio deles e com súbitas e vigorosas coronhadas, dispersa-os. Rompe prontamente as amarras de seu senhor, fá-lo montar a cavalo, dizendo-lhe para se afastar bem rápido. Ele se afasta também, mas a uma boa distância. De certo modo ele 


\section{fl. 76}

sauva la vie à son maître, lequel extrêmement sensible à un si important service, le déclara libre et lui fit un présent de 200000 Reis, proportionné à ses moyens. Le nègre qui lui était très attaché, voulut toujours rester à son service.

Un habitant de la campagne à Cuyabá, avait un esclave mulâtre très méchant; il y avait quelques mois que cet esclave s'était enfui, et le maître n'y pensait plus. Un jour, celui-ci s'en fut à la ville, et sa femme resta seule avec une négresse ; le mulâtre se présenta armé et lui intima de le suivre, en lui disant que si elle ne le fesait promptement, il la tuerait. Sa maîtresse lui dit: oui, je vais te suivre, mais comme je sais ce que tu veux de moi, et que peut-être tu ne me laisseras pas retourner dans ma maison, laisse-moi au moins emporter un paquet de linge. Le mulâtre le lui permet; elle entre dans sa chambre, prend un sac de farine, le met au milieu de quelque linge, fait un paquet, le remet à la négresse en

\section{fl. $76 \mathrm{v}$}

lui disant: laisse en sortant une trace de farine! Elle sort, marche la première, le mulâtre la suit de près, et la négresse avec le paquet sur la tête. Le mari arrive à la maison, appelle, personne ne répond. Il va de tout côté, et est frappé de voir la trace de farine; il la suit jusqu'à apercevoir la cabane de son mulâtre, devant laquelle il reconnait sa négresse: son extraordinaire aventure a mis son esprit en prévention, il arme son pistolet, et s'avance au galop. Le mulâtre sort au bruit, armé de son fusil; il déniche, et le feu ne prend pas: son maitre le blesse du coup de pistolet, et le mit hors d'état de nuire: transporté de fureur après avoir appris son procedé, il l'attache à la queue de son cheval; et le traîne jusqu'à sa maison.

Dans le temps où les jésuites Portugais fondaient et gouvernaient les missions portugaises voisines de celles des Espagnols du Paraguay, il arriva que dans une de ces missions ou villages, les indiens conspirèrent contre

\section{fl. 76}

salvou a vida de seu senhor, o qual, extremamente sensível a um tão importante préstimo, declarou-o livre e the deu de presente 200.000 réis, proporcional a seus meios. O negro que estava muito ligado a ele, desejou permanecer para sempre a seu serviço.

[5] Um habitante da zona rural em Cuiabá, tinha um escravo mulato muito mal intencionado; havia alguns meses que este escravo fugira, e o senhor não pensava mais nisso. Um dia, ele foi à cidade, e sua mulher ficou só com uma negra; o mulato apareceu armado e intimou-a a segui-lo, dizendo-lhe que se ela não o fizesse prontamente, ele a mataria. Sua senhora disse-lhe: sim, eu vou te seguir, mas como sei o que tu queres de mim, e que talvez tu não me deixarás retornar à minha casa, deixe-me ao menos levar uma trouxa de roupa. O mulato deu-lhe permissão; ela entra no seu quarto, pega um saco de farinha, enfia-o no meio de alguma roupa, faz uma trouxa, confia-o à negra

\section{fl. 76v}

dizendo-lhe: fores saindo, deixe um rastro de farinha! Ela sai, caminha na frente, o mulato a segue de perto, e a negra com a trouxa na cabeça. O marido chega em casa, chama, ninguém responde. Ele busca de todo lado, e fica assustado em ver o rastro de farinha; segueo até deparar com a cabana de seu mulato, na frente da qual reconhece sua negra. Sua extraordinária aventura pôs seu espírito de prevenção, ele arma sua pistola, e avança de galope. Com o barulho, o mulato sai, armado de seu fuzil; desentoca-se, e o tiro não sai. Seu senhor fere-o com tiro de pistola, e deixa-o sem condição de fazer mal algum: tomado de fúria depois de inteirado de seu proceder, ele o amarra à cauda de seu cavalo; e o arrasta até sua casa.

[6] No tempo em que os jesuítas portugueses haviam fundado e governavam as missões portuguesas vizinhas às dos espanhóis no Paraguai ${ }^{18}$, ocorreu que numa dessas missões ou povoados, os índios conspiraram contra 


\section{fl. 77}

leur missionnaire qui en même temps était leur curé, et cela à cause des vexations et arbitraires qu'il exerçait, principalement pour avoir à sa disposition leurs plus jolies femmes et filles: un jour ils se résolurent à le faire périr quand la nuit serait venue, en mettant le feu à sa maison, et se plaçant tout autour pour le tuer, s'il sortait pour se sauver: le curé fut averti, mais il repondit à celui qui l'avertissait: laisse-les faire; je ne crains pas les méchants; je resterai dans ma maison, et je ne périrai pas, parce que j'ai l'appui de Dieu. Celui qui l'avertissais crut que réellement il était saint, et attendit le miracle. Le curé feignit de ne rien savoir. Quand l'heure fut venue, où, selon le règlement, tout le monde devait être retiré, il se garda bien de rester chez lui; il fut se cacher dans le bois: quand il fut minuit, les conjurés furent entourer sa maison

\section{f1. $77 \mathrm{v}$}

et y mirent le feu; elle fut bientôt embrasée, car elle était de paille: les indiens ne le voyant pas sortir, crurent qu'il brûlait aussi. Quand la maison fut en cendres, ils se retirèrent: alors le curé fut se coucher sur les cendres; quand il fut jour, tout le peuple l'entoura, la plupart étonnés de cet événement, et les conjurés étonnés de le voir couché sur les cendres de sa maison: alors il se leva, et leur dit: c'est en vain que vous avez attenté à mes jours; je n'ai pas ignoré que vous vouliez me brûler dans ma maison; mais je n'en suis pas sorti, parce que j'ai l'appui du Seigneur: j’ai été au milieu des flammes, mais elles m'ont respecté, et je n'ai pas senti la moindre douleur: mes vêtements n'ont pas eu le moindre endommagement, et je suis resté intact au milieu des cendres: voilá une preuve certaine que tout ce que je fais

\section{fl. 77}

seu missionário que era ao mesmo tempo seu pároco, e isto por causa de humilhações e arbitrariedades que ele praticava, em especial por ter à sua disposição suas mais belas mulheres e moças. Um dia resolveram fazê-lo perecer quando a noite viesse, pondo fogo à sua casa, e postando-se todos ao redor dela para matá-lo, caso saísse para se salvar. $O$ pároco foi advertido, mas respondeu a quem o advertia: deixe-os fazer; não temo os malfeitores; ficarei em minha casa, e não morrerei, porque tenho o amparo de Deus. Aquele que o advertia acreditou realmente que ele era santo, e esperou o milagre. $O$ pároco fingiu nada saber. Quando chegou a hora, em que, segundo o regulamento, todo o mundo deveria se recolher, ele precaveu-se de ficar em casa; foi se esconder na mata. Quando deu meia-noite, os conjurados cercaram sua casa

\section{fl. 77v}

e para lá dirigiram fogo; ela logo se incendiou, pois era de palha: os índios não o vendo sair, imaginaram que ele queimava também. Quando a casa virou cinzas, eles se retiraram: o pároco, então, foi se deitar sobre as cinzas. Quando amanheceu, todo o povo cercou-o, a maioria surpresa diante do evento, e os conjurados surpresos de vê-lo deitado sobre as cinzas de sua casa. Então ele se levantou e lhes disse: é em vão que vocês atentaram contra mim; eu sabia que vocês queriam me queimar dentro da minha casa; mas dela não saí, porque tenho o amparo do Senhor. Fiquei no meio das chamas, mas elas me respeitaram, e eu não senti a menor dor; minhas vestimentas não tiveram o mínimo estrago, e eu permaneci intacto no meio das cinzas: eis aí uma prova clara de que tudo que faço 


\section{fl. 78}

est agréable au Seigneur: cette fois-ci je ne me venge pas du mal que vous avez voulu me faire; mais faites y attention, si vous continuez à être méchants de la même manière que j'ai su me livrer du feu, je saurai vous punir sévèrement.

Un de ces Certanistas de S. Paul, qui découvraient le centre de l'Amérique méridionale, traversait le désert de Goyaz à Cuyabá: cette dernière ville avait déjà été fondée par ceux qui avaient découvert la route des rivières par où l'on s'y rend en s'embarquant à Porto-Féliz: le Certanista découvrait le chemin de terre.

\section{fl. $78 \mathrm{v}$}

Il fut arrêté dans sa marche par des sauvages qui se préparèrent à l'attaquer: il avait peu de monde avec lui: il se sauva par un stratagème: il leur dit en langue Brésilienne (Lingua Geral Brésilienne) que s'ils ne le laissaient pas passer, il allait mettre le feu à leurs bois, leurs champs et leurs rivières: que tout allait brûler, et eux aussi. Et pour leur prouver la vérité de ce qu'il disait, il prit une de leurs calebasses, qu'il emplit adroitement d'eau-de-vie sans qu'ils s'en aperçussent, et fut à la riv. ere où il fit semblant de l'emplir d'eau: après il retourna à eux et y mit le feu: les indiens furent étonnés de voir l'eau brûler, et craignant qu'il ne fasse brûler leur petit univers, le laissèrent passer, et à sa prière, lui donnèrent les secours dont ils étaient capables.

\section{fl. 78}

é do agrado do Senhor. Desta vez eu não me vingo do mal que vocês quiseram me fazer; mas prestem atenção nisso, se vocês continuarem a ser maus, da mesma maneira que soube me livrar do fogo, saberei puni-los severamente.

[7] Um desses Sertanistas ${ }^{19}$ de São Paulo que descobriam o centro da América meridional, atravessava o deserto de Goiás a Cuiabá: esta última cidade havia já sido fundada pelos que tinham descoberto a rota dos rios por onde se vai embarcando em Porto Feliz; o Sertanista descobria o caminho por terra ${ }^{20}$.

\section{fl. $78 v$}

Ele foi barrado em sua marcha por selvagens que estavam prontos para atacá-lo. Ele tinha pouca gente com ele; e se salvou por um estratagema. Disse-lhes em língua brasileira (Língua Geral Brasileira) ${ }^{21}$ que se eles não o deixassem passar, poria fogo em suas matas, seus campos e seus rios: que tudo queimaria, e eles também. E para provar-lhes a verdade do que dizia, tomou uma dessas cabaças, que encheu habilmente de aguardente sem que eles notassem, e foi ao rio onde fez como se a enchesse de água. Em seguida retornou a eles e pôs fogo no líquido: os índios ficaram impressionados de ver a água queimar, e temendo que ele incendiasse seu pequeno universo, deixaram-no passar, e a seu pedido, deram-lhe a ajuda de que eram capazes. 


\section{NOTAS}

${ }^{1}$ Cf. Komissarov, 1994, pp. 42-4.

2 Além disso, o zoólogo Hasse abandonou a expedição ainda em Porto Feliz (cometeria suicídio em Campinas, algum tempo depois), e o astrônomo e geógrafo Rubtsov entregou-se ao alcoolismo e teve surtos psicóticos durante a viagem. Parece que, da equipe científica da monção, apenas o botânico Riedel e Florence terminaram todo o percurso 'sãos e salvos'.

${ }^{3}$ Os diários de campo de Langsdorff, publicados recentemente, apesar de sua incontestável relevância documental, não possuem a mesma densidade narrativa da obra de Florence, mais elaborada porque escrita a posteriori da viagem, a partir de anotações do seu diário de campo, mas não se confundindo com este. Sabe-se, também, que toda a parte final dos diários de Langsdorff, a partir de 13 de maio de 1828, foi redigida pelo próprio Florence (a pedido de seu comandante gravemente enfermo), até sua brusca interrupção, sete dias depois e sete meses antes de aportarem em Belém.

${ }^{4}$ A sugestão de Komissarov, a propósito de uma eventual inserção de referência sobre a história 7 em Viagem fluvial, mostrou-se improcedente. Esta história reporta a abertura do caminho terrestre entre as vilas de Goiás Velho e Cuiabá e não de Porto Feliz a Cuiabá, como anotou o insigne historiador (cf. Komissarov, op. cit., p. 43; Florence, 1977b, pp. 85-6).

${ }^{5}$ Em 15.7.1826, em seu diário, Langsdorff também se refere sumariamente a um "registro histórico" sobre a existência e destruição de um quilombo na área do ribeirão Tambaú, tributário do Tietê, de modo coincidente ao relato de Viagem fluvial. (Langsdorff, 1997, p. 148).

${ }^{6}$ Langsdorff (ibidem, pp. 121-3) igualmente ressalta no diário, entre as várias qualidades de Francisco Álvares, seus dotes de grande contador de histórias. Aqui também a indicação de Komissarov (op. cit., p. 43) de que um relato acerca de lutas e vingança entre familias ('História do rapaz que vingou seu irmão e cometeu sete assassinatos'), reportada por Francisco Álvares e Langsdorff, no trecho citado, coincide com a história 3 das anecdotes de Florence, revelou-se não pertinente, como se verá logo adiante.

${ }^{7}$ Cf. Bruno, 1967, pp. 21-40; Goes Filho, 1999, pp. 144-59.

${ }^{8}$ Os índios aqui são tomados em sua credulidade, num pólo, ou ferocidade, no outro. Não se especificam nações indígenas ou tribos, como ocorrerá, em pormenor, nas narrativas da Viagem fluvial, inclusive com o elogio, ao modo dos quilombos, de formas de comunitarismo igualitário no que diz respeito aos frutos do trabalho, como entre os apiacás (cf. Hardman, Kury, op. cit., em especial cap. VII). Em Algumas histórias, ao contrário, nem mesmo as reduções jesuíticas dos índios guaranis são vistas idilicamente (cf. história 6).

${ }^{9}$ Vale a pena comparar as descrições de Florence com as de autores clássicos da historiografia, como Capistrano de Abreu (op. cit., cap. 'O sertão') e S. Buarque de Holanda (1990, cap. 'Ouro' e 'Comércio de Cuiabá').

${ }^{10}$ Optamos por atualizar a ortografia do texto. Mantivemos a pontuação original, salvo em casos em que o sentido da frase pudesse escapar ao leitor atual. (N.T.)

11 Optamos por traduzir "anecdotes" do título original por 'histórias', no sentido lato de relatos, 'casos' ou narrativas, próximas da memória e da tradição oral. Isso porque o termo 'anedotas', transposto literalmente para hoje, sugere significado humorístico e galhofeiro à primeira vista, que se distancia do contexto semântico em que se situava o autor, bem como do próprio conteúdo das histórias, em que predomina o drama da violência social e não o modo cômico. (N.T.)

${ }^{12}$ Este título corresponde à primeira história. As demais seis narrativas não foram tituladas pelo autor. Para facilitar a localização pelo leitor, numeramos entre colchetes cada uma delas. (N.T.)

${ }^{13}$ Recolhida na memória popular e na tradição oral, esta história possui bastante verossimilhança com dados recentes da historiografia dos quilombos na região e no período indicados ao longo do relato. Sabe-se da existência de mocambos e quilombos nos limites extremos da capitania de São Paulo, em particular a partir dos anos 1770 e próximos à foz dos rios Paranapanema e Tietê. Também procedem as referências à expedição punitiva e de apresamento, bem como à relativa instabilidade e mobilidade geográfica dos quilombolas. Cf. Gomes, 1997; ver em especial cap. II, 'Uma outra história: quilombolas nas capitanias de São Paulo e Mato Grosso (1722-1811)'. (N.T.)

${ }^{14}$ Jaguáras, no original, como também o grifo de toda a expressão. A julgar pela única referência direta que faz a esta história em Viagem fluvial, os índios hostis da região poderiam ser os xavantes (cf. Florence, 1977b, p. 43). (N.T.)

${ }^{15}$ Guaytimirim, no original. Não localizamos nenhum topônimo idêntico ou similar como designação de fortificação militar nas fronteiras sul ou centro-oeste do Brasil colônia na segunda metade do século XVIII, época mais provável de ocorrência do episódio relatado. Poderia tratar-se de erro do autor na grafia, pois quando de seu registro era ainda novato com o português e com palavras de origem indígena ou africana. Ou, então, tratava-se de pequena guarnição fronteiriça e não exatamente de um forte, como sugerido. (N.T.)

${ }^{16}$ Trata-se de Francisco Álvares Machado e Vasconcellos, que era também oculista, intelectual humanista e líder do Partido Liberal em São Paulo. Tornou-se, depois de 1830, sogro de Florence, que casou-se com sua jovem filha Maria Angélica. (N.T.) 
17 À época, a região do Paraná, do ponto de vista político-administrativo, fazia parte das províncias de São Paulo, ao norte, e de Santa Catarina, ao sul. (N.T.)

18 Trata-se de menção às reduções de povos indígenas guaranis, que existiram ao longo dos rios Paraguai e Paraná desde o início do séc. XVII até meados do séc. XVIII, organizadas por jesuítas. (N.T.)

${ }^{19}$ Certanistas, no original. De fato, sertão era comumente grafado, à época, como 'certão'. A origem deste termo permanece polêmica. Considerado por muitos corruptela de 'deserto' ou 'desertão', esta versão foi contestada por Gustavo Barroso (12.7.1952), que defendeu a idéia de 'certão' ter-se derivado do idioma bunda, nativo de Angola, a partir de michitu, muchitu ou muchitum (que designava a selva mais distante e inóspita), transposto nos termos lusos arcaicos muceltão, celtão e certão. (N.T.)

${ }^{20}$ Sobre os caminhos terrestres nos sertões do Centro-Oeste, abertos na primeira metade do século XVIII, a partir de antigas trilhas indígenas, e sempre apenas um complemento às rotas fluviais, consultar Holanda (op. cit.); Abreu (op. cit.); Bruno (op. cit., vol. 6); e Goes Filho (op. cit.). (N.T.)

${ }^{21}$ Lingua Geral Brésilienne, no original. (N.T.)

\section{REFERÊNCIAS BIBLIOGRÁFICAS}

Abreu, João

Capistrano de

1963

Barroso, Gustavo

12 jul. 1952

Bruno, Ernani Silva

1967

Florence, Hercule

$1977 \mathrm{a}$

Florence, Hercule $1977 b$

Florence, Hercule 1829-1830a

Florence, Hercule 1829-1830b

Florence, Hercule 1829-1830c

Goes Filho, Synesio 1999
Capítulos de história colonial (1500-1800) \& Os caminhos antigos e o

povoamento do Brasil. 5a ed. rev. Brasília, Ed. UnB.

'Vida e história da palavra Sertão'.

O Cruzeiro, 24: 39, pp. 53-4.

História do Brasil: geral e regional, vol 6. São Paulo, Cultrix.

Viagem fluvial do Tietê ao Amazonas pelas provincias brasileiras de SãoPaulo,Mato Grosso e Grão-Pará (1825-1829).

Trad. Francisco Álvares Machado e Vasconcellos Florence. São Paulo, Masp.

Viagem fluvial do Tietê ao Amazonas de 1825 a 1829.

Trad. visc. Taunay. São Paulo, Cultrix/Edusp.

'Continuation de l'esquisse du voyage de M. de Langsdorff dans l'intérieur du Brésil, depuis sept. 1825 jusqu'en mars 1829. Par le 2e. dessinateur de ce voyage Hercule Florence. Livre deuxième'. Moscou, Academia de Ciências, fundo 63, inventário 1, manuscrito 8, fl. 1-70 (Cópias em microforma: Centro de Memória da Unicamp e Arquivo da Casa de Oswaldo Cruz).

'Quelques anecdotes brésiliennes'. Em Hercule Florence. Continuation de l'esquisse du voyage de $M$. de Langsdorff dans l'intérieur du Brésil, depuis sept. 1825 jusqu'en mars 1829. Par le 2e. dessinateur de ce voyage Hercule Florence. Livre deuxième. Moscou, Academia de Ciências, fundo 63, inventário 1, manuscrito 8, fl. 71-78 (Cópias em microforma: Centro de Memória da Unicamp e Arquivo da Casa de Oswaldo Cruz).

'Mémoire sur la possibilité de décrire les sons et les articulations de la voix des animaux'. Em Hercule Florence. Continuation de l'esquisse du voyage de M. de Langsdorff dans l'intérieur du Brésil, depuis sept. 1825 jusqu'en mars 1829. Par le 2e. dessinateur de ce voyage Hercule Florence. Livre deuxième. Moscou, Academia de Ciências, fundo 63, inventário 1, manuscrito 8, fl. 79-88 (Cópias em microforma: Centro de Memória da Unicamp e Arquivo da Casa de Oswaldo Cruz).

Navegantes, bandeirantes, diplomatas: um ensaio sobre formação das fronteiras do Brasil. São Paulo, Martins Fontes. 
Gomes, Flávio

1997

Hardman, F. Foot,

Kury, Lorelai

2004

Holanda, Sérgio

Buarque de

1990

Komissarov, Boris

1994

Langsdorff, G. H. Von 1997

Volney

[1979]
A hidra e os pântanos: quilombos e mocambos no Brasil (séculos XVI-XIX). Tese de doutoramento em história, IFCH/Unicamp, Campinas. (digit.)

Zoofonia: Hercule Florence e os registros da natureza falante.

São Paulo, Companhia das Letras (no prelo).

Monções. $3^{\text {a }}$ ed. ampl.

São Paulo, Brasiliense.

Expedição Langsdorff: acervo e fontes históricas São Paulo, Unesp; Brasília, Edições Langsdorff.

Os diários de Langsdorff, vol. II (São Paulo, 1825-1826).

Campinas, AIEL; Rio de Janeiro, Fiocruz.

Voyage en Égypte et en Syrie.

Paris/Haia, Mouton \& Co. $1^{\mathrm{a}}$ ed. em 1787. 